\title{
Virtual Learning Strategies during Covid-19: A Case Study of The University of Lahore, Pakistan
}

\author{
Tehmina Aslam*1, S. Mubashar Ali Shah Rizvi² \& Jawad Ahmad ${ }^{3}$ \\ 1. School of Integrated Social Sciences, The University of Lahore, Lahore, Pakistan. \\ 2. Research Society of International Law (RSIL), Lahore Office, Lahore, Pakistan. \\ 3. School of Law and Economics, University of Kassel, Kassel, Hessen, Germany.
}

\begin{abstract}
Due to COVID-19, the government of Pakistan had to take measures to bring about changes in almost all infrastructures, including that of education and decided to switch to a virtual learning environment and urged all educational institutes to adopt virtual learning strategies to facilitate student learning process. In an attempting to contain the virus instructed educational institutes to explore virtual space to continue learning process. The University of Lahore was one of the few universities in Pakistan that took the lead and decided to serve the learning purpose. However, due to cultural differences and dependency on traditional learning, most universities found it difficult to follow suit. The University of Lahore has crossed a milestone and emerged as a model for other universities across country. The virtual learning strategies that have been adopted by the University are no less than international standards and the administration have been working tirelessly to ensure the smooth running of this digital education system. Based on the student survey and faculty interviews, this study recommends regular virtual trainings by educational institutes and to overcome the issues of internet connectivity and electricity in the country as a whole to better deal with the challenges that lie ahead.
\end{abstract}

Keywords: Virtual Learning, Virtual Learning Strategies, COVID-19 Pandemic, Education Challenges, Learning Opportunities, Traditional Learning, Online Learning.

\section{Introduction}

Learning is a permanent change in the behaviour that comes with experience and practice. (Lachman, 2010). This is a traditional definition of learning that is somehow difficult to apply on extraordinary circumstances and pandemics such as COVID-19. This pandemic has brought an unprecedented challenge not only for the governments but also for every individual across the world. COVID 19, is generally known as coronavirus that started spreading in China during the late 2019. World Health Organization declared coronavirus as Pandemic on $11^{\text {th }}$ March 2020, in the wake of increasing number of affected people and deaths (World Health Organization, 2020). As of April 2021, the worldwide death toll has reached 3.01 million with total number infected being 140 million.

The COVID 19 crisis has created an environment of uncertainty and anxiety among masses around the world. As described by international health organizations, the crisis is going to stay for long and people will have to learn to live with it. This means bringing about lifestyle 
changes on every level and for every individual, no matter their age. The pandemic is not to be taken lightly and carelessly because of the rapid spread and severity of the disease. If not controlled on time, the virus can be disastrous for global peace and can also cause economic and social collapse. This pandemic has become a challenge for all spheres of life and unsurprisingly halted the education sector as well.

The virus can be transmitted easily through people-to-people contact and also from touching surfaces, which are already contaminated. As it is an entirely new and novel virus, the world does not know much about how to tackle it. In order to reduce the rapid spread of the virus it was required to maintain social distance and therefore, necessitated the need to shut down all businesses of life including educational institutes. Everywhere around the world, governments announced strict lockdowns and encouraged everyone to stay at home. After assessment of the situation, it was decided globally to continue educational activities through online learning to minimize disruption in the learning process.

Once the pandemic of COVID-19 hit the world, government of Pakistan had to take measures to bring about a new way of life for everyone. Pakistan announced lockdown on $17^{\text {th }}$ of March 2020 and also suspended all international travels to contain the wide spread of COVID 19. This included changes in almost all infrastructures, including that of education. To avoid chaos and disconnect with learning activities, governments decided to switch to a virtual learning environment. This proved to be a herculean task for most institutes as a majority of them were not well versed in technology and its advancements. It was difficult in Pakistan to switch to online learning easily because of cultural differences as education system in Pakistan is mainly based on traditional learning. However, the Higher Education Commission instructed all educational institutes explore virtual space and adopt virtual learning strategies and resume learning process immediately. After a lot of problems from both university administrations as well as students, who were not equipped to deal well with online learning, the online classrooms took off.

The University of Lahore, the largest private sector university in Pakistan and second largest among public-private universities in terms of students' strength, coming from all corners of Pakistan and abroad, studying across 5 campuses, went for online learning programs in less than a month after countrywide lockdown was announced. This study on 'Virtual Learning Strategies during the COVID 19', discusses about the concept of virtual learning and widely practiced virtual learning strategies. The University of Lahore has been taken as a case study and a success story of implementing all required virtual learning strategies in line with government policies and Higher Education Commission's recommendations. The study examines the challenges and strengths of the transition period from face-to-face learning to virtual learning that includes training of faculty and students and also the technical capacity building of University's technical staff.

The main focus of this study is: a) virtual learning strategies adopted by The University of Lahore; b) challenges faced by the University's administration, faculty members and students; c) strengths and weakness of virtual learning strategies; d) road ahead to adopting online platform as a permanent learning tool; and e) lastly, this study will discuss the findings of the study followed by recommendations for a better learning environment.

A lot of literature has been produced in the last few decades for the virtual learning suggesting 
numerous strategies to be adopted in online classrooms. However, the extraordinary times of COVID 19 pandemic has created immense space for researchers who wanted to explore this field of virtual learning. This study is a contribution and addition to already existing literature on virtual learning strategies. The case study of University of Lahore has been chosen carefully as the institute has shown commitment towards quality education even during the challenging times. The University was one of the few institutes that went online in less than a month of the lockdown. The institute is running almost 12000 courses online and more than 40 thousand students are getting education through online system.

Starting off with the literature review, the article cites multiple sources for the benefits of virtual learning. The research methodology is next, along with descriptions of the study participants and the measures taken. The virtual learning environment and virtual learning strategies expound upon what strategies were needed in the crisis of COVID-19 and how the University of Lahore specifically adapted its infrastructure to incorporate them. Quantitative data analysis and the discussion are the next steps of the article, ending with the findings from the study, the conclusions drawn and the recommendations given.

\section{Literature Review}

The concept of traditional leaning is based on the lifelong learning activities that an individual undertakes throughout his life to improve knowledge and skills. These educational activities usually take place in a physical space, where students go to an educational set up (Hassan et al., 2014). According to Konard Lorenz's theory of instinctive behaviour, learning is inherited and can only be enhanced through practice (Griffiths, 2004). However, the 2020 pandemic created unprecedented times that were not experienced before by people, states and international organizations. These challenging times provided a wide space to virtual learning, that was already under consideration by governments, scholars and practitioners and was already been practiced internationally and in Pakistan. The government of Great Britain introduced an e-learning strategy, considering the dominant change information technology could bring and the committee of this e-learning strategy described it as 'an important tool because it can contribute to all the Government's objectives for education to raising standards; improving quality; removing barriers to learning and participation in learning; preparing for employment; upskilling in the workplace and ultimately, ensuring that every learner achieves their full potential" (Pittard, 2004).

Similar views are presented by Chen (2003) in her article 'continuous learning comes to be seen more and more as a necessity for almost everyone in our rapidly changing and increasingly global society, the demand for more flexible educational environments increases accordingly'. Young and Lewis (2008) described virtual learning in the context of cost effectiveness and argued that the recent technological advancement has greatly changed the way the educational institutes deliver courses from distance as they see distance learning an effective means for sustaining growth. The debate on virtual learning started several decades ago but the concept of virtual learning is not new to humankind as it started with the wide spread of globalization around the world in the 1960s with the rise in computer technology. However, the availability and accessibility of the information and the concept of self-learning actually comes from the work and thinking of John Amos Comenius, who focuses on the phenomenon of selfunderstanding and self-learning of human beings (Semradova \& Hubackova, 2013). 
The basis of self-learning is based on collaboration and innovation in knowledge and communication. Historically the introduction of computer provided the opportunity to likeminded people to explore this new domain, but the advance technology today became a saviour of education system around the globe during the COVID 19 pandemic. According to Li and Lalani (2020), the demand of online learning has significantly increased during the 2020 pandemic and many universities have adopted the online system successfully. But there are many challenges to overcome i.e., bad internet connections, availability of resources in disadvantageous areas and lack of trained staff. However, an interesting fact that has been mentioned in this study is that student taking online classes are considered to retain more knowledge than in physical classes. Thus, proving the $17^{\text {th }}$ century hypothesis on effectiveness of self-learning (Li \& Lalani, 2020).

The process of virtual learning can be carried out through effective strategies integrated into the educational system. As argued by Hiltz and Turoff (2005) in 'Education goes digital: The evolution of online learning and the revolution in higher education;' the transformation of educational activities will require considerable modification in the next 50 years because the e-learning process is a complete change in behaviour from teacher-centric method to enhanced constructivist cooperative method in almost all parts of the world. As described by Hilts and Turoff (2005), e-learning is not a quick-fix but a total transformation of educational activities. The process, according to Cameron and Green requires complete preparation, capacity building, trust and reinforcement in the thinking process of all parties involved. This is collaborative practice and organizational development (Cameron \& Green, 2019).

\section{Conceptual Framework}

The concept, aspects, and strategies of the virtual learning are discussed as follows:

\subsection{What is Virtual Learning?}

The wide-spread use of virtual learning platforms created the need to understand this concept first. According to the dictionary of foreign words 'Virtual means the possible, which can be done under certain circumstances (Dictionary of Foreign Words, 1990). Virtual learning is the process of learning through online platforms using computer and that is away from traditional learning environment of face-to-face learning in an actual classroom space. This is, however, difficult to define the e-learning process in global context. Capper in 2001 described it as Internet-based learning by practitioners of the field (Capper, 2001). While Watson has discussed virtual learning in the context of blended strategy of online classes that compensate the face-to-face learning through video lecturing (Watson, 2013).

\subsection{Virtual Learning Environment}

Virtual learning environment is a specially designed space for online learning. According to Dourish "virtual learning provides social space to people who wants to learn and disseminate that knowledge, as spaces take their sense from configuration of brick, mortar, wood and glass, places take their sense from configurations of social actions. Places provide what we call appropriate behavioural framing" (Dourish, 1999). Virtual learning environment is the space, where learners can learn and incorporate different strategies of efficient learning. For example, in an on-campus class, teachers might be focusing more on paper assignments, projects and 
quizzes but in virtual learning environments they will have to come up with ideas that could fulfil the purpose of virtual learning.

Following aspects of the virtual learning environment can make online learning more useful:

- Information can be used in educational interactions i.e., doing a project in table form or presenting argument through a poster that could be stored for later utilization.

- Virtual learning provides a great platform to get information from multi-authors. Many teachers, students and practitioners are contributing in knowledge sharing and developing an online workflow.

- An extremely important aspect of virtual learning environment is the information about the real authors. Learners cannot give an argument with their names and have to be truthful while submitting the information.

- The role of technical teams in maintaining data and information becomes crucial in virtual learning settings.

- The purpose of virtual learning is to evolve better, and it is important for all entities involved to learn and share the information with others.

In the contemporary world technology has made it essential for everyone to acquire themselves with the knowledge and skills of virtual learning environment to become an active member of virtual community.

\subsection{Virtual Learning Strategies}

Virtual learning requires facilitation and engaging students in virtual learning activities through different strategies to enhance student participation and attention in the learning process. It can lead to a cooperative and collaborative environment of learning for everyone involved in this. The purpose of virtual learning activities should be to enhance student's reasoning and analytical skills as described by Bozanta and Mardikyan (2017) that teachers must encourage students for complex-reasoning and assist them in the process that will surely boost their confidence. In order to carry out this task teachers need to be fully equipped with the integrated system of virtual learning.

Some scholars like Greton (2000) believe that virtual learning is a continuation of traditional leaning process and does not introduce anything new but only add into the already existing learning environment. While Kelly and Roberts have explained the important of virtual learning strategies on human development in terms of cognitive enhancement and behavioural change. They further explained that when a teacher develops lectures for online class and also provide material to read and judge followed by constructive discussions and peer reviews, there are more chances of progressive development that cannot be achieved in traditional learning (Kelly \& Roberts, 2000).

Virtual learning strategies are based on the conscious efforts of the teachers and management to create an environment that can facilitate learners and to avoid any mal-functioning or technical faults. It does not only consist of teacher's efforts to plan and develop lectures, but it is based on the integrated institutional approach. It includes planning and decision making by higher authorities i.e., what platforms to choose for online lecturing, providing internet facility, 
what will be the delivery methods i.e., video lecturing or audio and how students will be assessed on their online learning.

\section{Research Methodology}

This is an exploratory and descriptive study based on mix method approach. It includes qualitative analysis of the quantitative data that has been collected from students, faculty members and executive body of the university to better explain the steps taken to make it a smooth transition. Thus, the study while using the mix method approach, includes both qualitative description and quantitative analysis. It is a descriptive observational study that has been conducted over the 30 days period. These four weeks is the time when the University has gone online again in the October-November 2020, as a result of second wave of COVID 19. Tools for data collection comprises of primary and secondary sources. Primary sources include questionnaire and interviews. Quantitative data has been collected from students of School of Integrated Social Sciences, The University of Lahore (UoL) and Interviews have been conducted from the higher authorities of the university, faculty members and IT department. Secondary resources that have been consulted include books, journal articles, newspaper and magazine articles for a better understanding of the subject under discussion.

\subsection{Study Participants}

The data has been collected in three phases. In the first phase data was collected from $3^{\text {rd }}$ to $7^{\text {th }}$ semester undergrad students who are taking virtual classes and have been a part of this transition process. Total number of students participated in this study were 70 (42 male students and 28 female students). During second phase, interviews were conducted from 15 faculty members. The third and last phase added significant value to the research as the interviews were conducted from the higher authorities and head of IT department. These were the people who were leading the whole learning management system (LMS). The objectives and procedure of the study was clarified to the participants and consents were taken. For ethical reasons student's identity has been kept anonymous.

\subsection{Measures}

The virtual learning strategies at the UoL during the challenging times of COVID 19 included online lectures, quizzes, assignments, webinars, tutorials and student presentations to fulfil the course requirements and achieve the course objectives. Students have filled a satisfaction survey on a 1 to 5 Likert scale with the measures that have been taken to somehow compensate face-to-face learning with e-learning. Faculty members have been interviewed to observe and analyze the challenges they have faced and virtual learning strategies they have adopted to make their online lectures more interactive. Interviews from the administration provided insights on timely management of switching to virtual learning environment.

\section{Virtual Learning Strategies Adopted by UoL during COVID-19: An Analysis}

\subsection{Key Informants Views: A Qualitative Aspect}

COVID 19 has brought many challenges and opportunities for education providers to learn and adopt. Universities around the globe implemented online learning strategies to facilitate the transition from on-campus learning to virtual learning environment. This section presents a 
detailed analysis of interviews conducted from teachers and university's administration on virtual learning strategies adopted during the time of COVID 19. Finally, a comprehensive description has been given on the technological integration of online software and tools available for virtual learning by the University's technical team.

The University of Lahore as a private sector university took the lead and utilized its own resources to go online within a month of lockdown and since March, university's administration is trying to improve the quality of available technical tools and also quality of online student-teacher interaction. Awais Rauf - Chairman University of Lahore in his interview with the author mentioned that "the university is evolving with the ongoing circumstances as the learning activities have never been entirely shifted online before. The university was already using a few online strategies but mostly have been developed during the time of pandemic. It is a secure system and students have learnt to use it." The strategies of University of Lahore can be divided into five phases:

a) First phase: is based on planning and development, that is described in terms of planning for creating virtual learning environment and choosing right tools for virtual learning

b) Second phase: mainly dealt with the decision making on recommendations of authorities and IT personnel

c) Third phase: transferring of courses and student enrolment to new virtual tools

d) Fourth phase: it is the most crucial phase in which teachers and students familirized with virtual classes

e) Fifth phase: Evaluation and feedback, it also includes improvement in the quality of technical tools and in the quality of teacher-student interaction.

Nasir Mahmood, Pro-Rector, the UoL, in his interview explained the challenges, the University had to face to start and maintain the virtual learning environment. According to Mahmood the greatest challenge was the selection of best suitable technical platform for e-learning. The University had its own data centre and ISO cloud and some of the academic departments at the University were already using Moodle (course management system) to conduct online classes, that provided an edge to the technical team to start building up courses on Moodle. In the short span of two weeks, the technical team was able to transfer all courses and configured it to other data systems of universities that are SAP and SIS. The Pro-Rector also highlighted that it was not an easy task, but the efficiency of our technical team helped the University to act in time. The challenges faced during this process as described by him are:

- Creating 6000 courses on a new platform but it was managed shift all courses from already existing learning management system.

- Enrolment of more than 40 thousand students on a new platform. But it became less hectic with the configuration of student data from existing data system to new platform.

It took about four weeks to create the virtual classrooms, to enrol students, and to choose the right tool to deliver the lecture. It was a technical challenge to choose among multiple options of different software/systems, but the management chose Zoom for video lecturing and precured its licensing. This is how the University created a virtual learning environment for their staff and students.

Another major challenge that the University of Lahore had to face during this transition process 
was to adopt virtual learning strategies and to train the staff and technical team for this quite new learning style. As many people were naive to face the camera and deliver lectures online. To avoid glitches and to overcome this initial challenge, a team of IT personnel was created that equipped themselves with required skills and provided training to the teaching and administrative staff.

The University started 'E-ticketing system' to address the grievances of students who were taking classes from home. Immediately after going into the lockdown, a 'University Call Center' was opened to listen to all complaints and was directing issues to related departments. Later an email system was generated through which students could send email to the university official email address for virtual support and against their email the system generates a ticket that remains valid until the issue get resolve within given timeframe. According to the University record seventy-one thousand tickets have been generated in the initial months of lockdown, out of which $89 \%$ issues were resolved timely and $11 \%$ complaints took a little while to get resolved.

This is the first-time education system in Pakistan has shifted to online learning at all levels, under this circumstance it is crucial to highlight the conditions that influence the effectiveness of online learning the most. The interviews with higher authorities of the university provided knowledge about different parameters that are influencing the online learning.

- The most important is use of technology and creating virtual classrooms similar to on campus classrooms

- Nature of the subject (theoretical subjects can be covered through virtual classes but lab work cannot be replaced with video lectures)

- Training of teaching staff, especially those who are not very well equipped with technological knowledge

- Disruption in internet connectivity and no electricity

- Lack of technological equipment and shared space at home

Another important aspect that has been addressed is the quality of online learning. University of Lahore has always focused on capacity building and automating the education strategies. During the time of COVID-19 the biggest challenge was the conduction of timely lectures. An inclusive monitoring system was introduced to deal with this consisting of university's monitoring cell and departmental monitoring teams to check the quality and environment of online classes. Second challenge was putting teachers in front of camera. Almost 10 to 15\% teachers had problems in facing camera and also to record the lecture. The university's technical team provided them initial training on their body language, voice facial expressions to face the camera efficiently. Although only 10 to $15 \%$ teachers have faced this issue, but We also provided them training. Body language, voice language, face cam with efficiently. Furthermore, focal persons from every department were nominated and received training to further support their department.

\subsection{Integration of Online Software and Tools: Analysis of Technological Aspects}

University of Lahore has an online enrolment system from last ten years with the vision to reach to every corner of Pakistan and then to go global, mentioned by the University's Chairman, Awais Raoof, in his interview. University used a combination of different resources; 
some were open source, and some were precured and purchased. According to Usman Javaid Malik 'Advisor Information Technology, University of Lahore, the university become Pakistan's first university to move to Student Life Cycle (SLCM) by SAP which allows the same in a more user-friendly way as the system allows more than 40 thousand students to enrol automatically in a self-service manner online. Technological integration of online software and tools have been discussed by Mr. Malik in his interview are:

a) Level 0: Campus management: SAP, SLCM / ERP

b) Level 1: Moodle LMS (internally called slate)

c) All these systems are integrated with G Suite by google for authentication, sms/email gateway for communications and zoom for class delivery.

Furthermore, University of Lahore is Pakistan's only university to be not only following ITSM model for IT service excellence but currently in process to become first one to be ISO 20000 certified. That involves comprehensive quality cycle including continuous staff training. The university can serve as the role model in education sector in Pakistan to support the educational activities in virtual learning environment. Authors have tried to give a brief step by step procedure that can be replicated in other institutes in Pakistan in Figure 1.

Figure 1: Step by Step Flow Chart for Creating Virtual Learning Environment

\begin{tabular}{|l|l|}
\begin{tabular}{|l|l|} 
Planning and Policy making at \\
the administrative level
\end{tabular} & $\begin{array}{l}\text { - Decision-making body of institute } \\
\text { - Technical team }\end{array}$ \\
\hline Implementation of Policies & $\begin{array}{l}\text { - Creation of Virtual Learning Environment } \\
\text { - Selecting right tools/software for online classes }\end{array}$ \\
\hline Training and Execution & $\begin{array}{l}\text { - Techers and Admin staff trainings } \\
\text { - Student trainings }\end{array}$ \\
\hline Monitoring and Evaluation & $\begin{array}{l}\text { - Feedback mechanism from students } \\
\text { - Feedback from teachers }\end{array}$ \\
\hline
\end{tabular}

\subsection{Students' Feedback: A Quantitative Analysis}

In this section, the quantitative analysis of student survey has been presented regarding the online classrooms, students have to attend, and the problems faced by them. It also provided the space to students to give their recommendations about virtual learning and how the virtual learning environment can be enhanced through student friendly teaching methodologies. The data presents in table- 1 shows that virtual learning has not fully compensated the face-to-face classroom learning as $33.8 \%$ students have decided to stay neutral on this question. But $22 \%$ agree ratio is a good sign towards adaptation of virtual learning environment. It was extremely 
important for the university to take required and timely measures. According to student survey University's administration was helpful to handle their grievances and problems during the transition period. Majority of students are satisfied with teacher interaction through online platforms and a satisfactory number of students believe that virtual learning strategies adopted by their teachers i.e., online quizzes, assignments and webinars have improved their performance in class. However, some student believe that online learning does not provide enough time for their educational activities.

Students were asked to give their recommendations on virtual learning environment as they have been greatly affected by the challenging circumstances of COVID 19. Learning from home has created problems for students who are living in joint family system, doing household chores and have to share space and technical equipment's (computer / laptop) with other family members. Most of them have favoured on-campus classes because they believe that online classes create a disconnect between them and their traditional learning environment. They cannot see their teachers in person and yet unable to perform in a manner that is actually required for their degree programs.

Other important concerns that have been raised by students are the internet connectivity and troubles linked with inter-city travel. According to them government and university authorities should make sure to provide internet availability to all students so that they can attend their classes without disruption. Furthermore, students have recommended improvement in regular teacher and student trainings to acquaint them with virtual learning environment. Lastly, they do understand the hard times everyone is facing due to these extraordinary circumstances, but they believe that authorities should consider making more student friendly policies i.e., evening classes and widespread availability of internet.

\begin{tabular}{|l|c|c|c|c|c|}
\hline \multicolumn{2}{|l|}{ Table 1: Student Survey for Virtual Learning } \\
\hline Questions & $\mathrm{SD}(\mathrm{n} \%)$ & $\mathrm{D}(\mathrm{n} \%)$ & $\mathrm{N}(\mathrm{n} \%)$ & $\mathrm{A}(\mathrm{n} \%)$ & $\mathrm{SA}(\mathrm{n} \%)$ \\
\hline $\begin{array}{l}\text { Virtual learning has compensated the } \\
\text { suspension of learning on campus during } \\
\text { COVID-19 }\end{array}$ & 14.7 & 22.1 & 33.8 & 22.1 & 7.4 \\
\hline $\begin{array}{l}\text { Technical issues faced by you during the } \\
\text { transition period were timely handled by } \\
\text { University's administration. }\end{array}$ & 13.2 & 14.7 & 32.4 & 30.9 & 8.8 \\
\hline $\begin{array}{l}\text { University's administration was helpful in } \\
\text { listening your grievances during virtual } \\
\text { learning. }\end{array}$ & 20.6 & 14.7 & 20.6 & 38.2 & 5.9 \\
\hline $\begin{array}{l}\text { Your university's efforts for the smooth running } \\
\text { of your virtual classes are admirable. }\end{array}$ & 11.8 & 16.2 & 36.8 & 29.4 & 5.9 \\
\hline $\begin{array}{l}\text { Online interaction with your teachers has been } \\
\text { satisfactory. }\end{array}$ & 20.6 & 4.4 & 23.5 & 42.6 & 8.8 \\
\hline $\begin{array}{l}\text { Virtual learning strategies by your teachers have } \\
\text { improved your performance in class }\end{array}$ & 26.5 & 17.6 & 22.1 & 27.9 & 5.9 \\
\hline Online quizzes and projects are useful. & 26.5 & 22.1 & 8.8 & 27.9 & 14.7 \\
\hline $\begin{array}{l}\text { Online learning provides you enough time for } \\
\text { your educational activities. }\end{array}$ & 20.6 & 20.5 & 20.6 & 23.5 & 8.8 \\
\hline $\begin{array}{l}\text { Your overall virtual learning experience during } \\
\text { the COVID 19 Pandemic is satisfactory. }\end{array}$ & 19.1 & 26.5 & 16.2 & 30.9 & 7.4 \\
\hline SD: Strongly Disagree, D: Disagree, N: Neutral, A: Agree, SA: Strongly Agree & & \\
\hline
\end{tabular}




\subsection{Discussion and Key Findings}

The year 2020 has been the most dramatic in terms of human interaction and regular life activities. The COVID 19 pandemic has created drastic challenges in history for the educators and students with the great disruption in education process. Although, people are living in $21^{\text {st }}$ century and almost everyone is owned technological tools such as advance mobile phones, computers and laptops, still COVID 19 created big hurdles for everyone to get use to the virtual learning environment. According to a policy brief published by United Nations in August 2020 on 'Education during COVID-19 and beyond' this pandemic has affected almost 1.6 billion around 190 countries in all continents.' Furthermore, this study has highlighted that 99 percent of students in developing countries have been affected by the closure of educational institutes. In developing countries due to the lack of resources the education system was already in its evolution process and the pandemic has further slowed down the process.

However, there are many educational institutes around the world which decided to take the appropriate measures even beyond their capacities to serve the purpose and to continue providing learning space to students. The University of Lahore is one of the success stories in Pakistan, that adopted virtual learning strategies and equipped itself with all required tools within the timeframe of a month, when many government sector universities were unwilling to explore the new learning space.

Virtual learning strategies adopted by the University of Lahore, were not only based on lecture delivery but the administration decided to have an integrated approach with long term goals. As explained by Awais Rauf (Chairman - UoL) that the threat of closing the university in these unprecedented times is always there and having this online system is a big support to continue educational activities. Nasir Mehmood (Pro-Rector - UoL) further explained that the University has a very well-defined mechanism that include technological platforms, human trainings, best available resources and individual capacity building.

Furthermore, not only students but teachers and administration had to face a number of challenges and the biggest was to get used to the online learning. As educational institutes in Pakistan follows traditional learning environment and many educators and students did not have any prior experience of virtual classes. Other challenges as explained by the Advisor Information Technology - University of Lahore, the bad internet connections in remote areas of Pakistan, students coming from low-income families and even middle-income families had great difficulty due to the lack of equipment i.e., computers and laptops as they will have to share these with other family members as well. Students' anxiety due to unforeseen circumstances, as lose of their family livelihood and jobs made education much smaller problem to a household.

However, student survey and faculty interviews have provided the knowledge on university's efforts to gracefully deal with these challenges and making The University of Lahore among those universities who have followed international standards within their own capacity to contribute in the learning process and also to give a positive image of Pakistan. As mentioned by the Advisor Information Technology that the University has surpassed all benchmarks of the virtual learning system and also offered support to Higher Education Commission Pakistan on policy making and training of those institute who are behind in adopting virtual learning environment. 
Similar remarks have been shared by the Chairman of the University that the University of Lahore had no other option, being a private sector university to carry out the educational activities online and in doing so university's administration tried to do its best in incorporating all available technical tools and training the staff to use those tools.

This study was based on the case study of University of Lahore and few key findings have been given below after the analysis of data that was collected from students, teachers and administrative authorities:

a) human interaction and shared physical environment have their own dynamics that cannot be replaced by virtual learning as it has its own limitations and challenges.

b) Virtual learning environment is a great platform created by the technological advancement around the world and many people in developed world are fully equipped with the skills to use these spaces. This study has found that many people in Pakistan lack basic computer skills. Even the young generation does not focus on learning strategies.

c) Students shows interest in online learning, as it saves time and money on travel but the domestic issues i.e., household chores, lack of technological equipment and lack of practice become a great hurdle in their learning process.

d) Many educational institutes in Pakistan lack the will and resources to explore the virtual learning platforms.

e) Private sector universities have the capacity to better incorporate online learning tools that public sector universities.

f) Virtual learning environment has created a new wave of technological advancement within Pakistan as many people have started acquiring knowledge about virtual learning.

g) Unprecedented times like COVID 19 is not only a challenge but it provided opportunities to have an integrated educational approach at national level and a collaborative approach at institutional level.

h) Regular interaction with online learning can make educators more skilled and can add value to already existing education system

i) It is strongly felt that based on our findings, University of Lahore can be taken as a success story of innovative learning strategies during the pandemic, and that its strategies can be replicated elsewhere with a high probability of success across Pakistan.

\section{Conclusion and Recommendations}

As mentioned by World Health Organization, Corona virus will stay for a longer period and will continue to disrupt educational activities. As we have already seen, the world came to a standstill with every facet of life interrupted when the lockdowns started. Therefore, Substantial policy making is required in these extraordinary times to avoid any gaps in the learning process. These gaps, if they come, can greatly affect the reasoning capacities of not only students but also educators. Furthermore, it may result in a dire future for all those students affected by the lack of quality education that they are getting during this pandemic. However, although, there is a huge fiscal pressure on countries and the families are facing great financial challenges, there are also equal opportunities available for those who do not want to quit and continue their mission. The University of Lahore is one of those entities who did not want to stop the development process in education sector and they took up the mantle and switched their teaching processes around very quickly and to great success. It can be taken as the virtual learning model by other institutes around Pakistan to follow the good practices of the university in times of crisis. For developing countries, it is crucial to keep going in order to avoid financial 
gaps and gaps in the development process. The University of Lahore has greatly contributed in the continuity of the learning process in Pakistan and supported the country's efforts by incorporating all possible modes of virtual learning. Lastly, the efforts of the University in supporting students and training their teachers are the key to rise and build back better.

After going through all the findings and study on virtual learning strategies, some key recommendations have been presented, which are as follows:

a) The government in collaboration with educational institutes should start regular virtual training programs not only for young generation but most importantly for older generations, who are not much familiar with the technology.

b) Uninterrupted availability of internet and electricity should be ensured by the government

c) Government and educational institutes should support deserving students financially and provide them the basic equipment i.e., computers / laptops and internet devices

d) The policy of public-private partnership should be adopted, and private business should also play their role in the social and economic development of the country

e) The approach of individual realization should be adopted by students and teachers to make the virtual learning process successful.

\section{References}

Bozanta, A., \& Mardikyan, S. (2017). The Effects of Social Media Use on Collaborative Learning: A Case of Turkey. Turkish Online Journal of Distance Education, 18(1), 96-110. https://eric.ed.gov/?id=EJ1124963

Cameron, E., \& Green, M. (2019). Making Sense of Change Management: A Complete Guide to the Models, Tools and Techniques of Organizational Change. Kogan Page.

Capper, J. (2001). The Emerging Market for Online Learning: Insights from the Corporate Sector. European Journal of Education, 36(2), 237-245. https://doi.org/10.1111/1467-3435.00062

Chen, T. (2003). Recommendations for Creating and Maintaining Effective Networked Learning Communities: A Review of the Literature. International Journal of Instructional Media, 30(1), 35-44. https://search.proquest.com/openview/7694679edecb823835c032cf4a7ea173/1?pqorigsite $=$ gscholar $\& \mathrm{cbl}=30932$

Dictionary of foreign words. 1990. M. Rus. lang.

Dourish, P. (1999). Where the Footprints Lead: Tracking Down other Roles for Social Navigation. Springer.

Garten, E. D. (2000). Providing intellectual resources through technology to transnational virtual universities: good practice and lessons learned from world-class examples. Higher Education in Europe, 25(3), 361-371. https://doi.org/10.1080/713669276

Griffiths. E. P. (2004). Instinct in the '50s: The British Reception of Konrad Lorenz's Theory of Instinctive Behavior. Biology and Philosophy Special issue on Animal Behavior. https://core.ac.uk/download/pdf/191844765.pdf.

Hassan, A. Abiddin, Z, N. \& Yew, K, S. (2014). The Philosophy of Learning and Listening in Traditional Classroom and Online Learning Approaches. International Journal of Emerging Technologies in Learning. http://dx.doi.org/10.5539/hes.v4n2p19 
Hiltz, S. R., \& Turoff, M. (2005). Education Goes Digital: The Evolution of Online Learning and the Revolution in Higher Education. Communications of the ACM, 48(10), 5964. https://doi.org/10.1145/1089107.1089139

Jason. J. W. Jeremy, N. \& Trifonas, P, H. (2006). The International Handbook of Virtual Learning Environments. Springer.

Kelly, P. \& Roberts, L. (2000). Challenges for University Administrators in the Online World. Perspectives, 4(4), 95-99. https://doi.org/10.1080/13603100050145155

Lachman. J. S. (2010). Learning is a Process: Toward an Improved Definition of Learning. The $\begin{array}{lllll}\text { Journal of } & \text { Psychology. } & 131 & \text { (5), } & \text { 477-480. }\end{array}$ https://doi.org/10.1080/00223989709603535

Li, Cathy. \& Lalani, Farah. (2020). The COVID-19 pandemic has changed education forever. This is how. World Economic Forum. https://www.weforum.org/agenda/2020/04/coronavirus-education-global-covid19online-digital-learning/

Pittard, V. (2004). Evidence for E-learning Policy. Technology, Pedagogy and Education, 13(2), 181-194. https://doi.org/10.1080/14759390400200179

Semradova, I. \& Hubackova, S. (2013). Learning Strategies and the Possibilities of Virtual Learning Environment. Procedia - Social and Behavioural Sciences. 83, 313-317. https://doi.org/10.1016/j.sbspro.2013.06.061

World Health Organization. (2020). WHO Director-General's Opening Remarks at the Media Briefing on COVID-19. https://www.who.int/director-general/speeches/detail/whodirector-general-s-opening-remarks-at-the-media-briefing-on-covid-19---11-march2020

Young, A., \& Lewis, C.W. (2008). Teacher Education Programmes Delivered at a Distance: An Examination of Distance Student Perceptions. Teaching and Teacher Education, 24(3), 601-609. https://www.learntechlib.org/p/76085/

Watson, J., Murin, A., Vashaw, L., Gemin, B., \& Rapp. C. (2013). Keeping Pace with K-12 Online \& Blended Learning: An Annual Review of Policy and Practice. Evergreen Education Group. https://files.eric.ed.gov/fulltext/ED565714.pdf 
Annexure 1: Questionnaire for Key Informant Interviews

\begin{tabular}{|l|l|}
\hline Name of Interviewee & \\
\hline Designation & \\
\hline Email ID & \\
\hline Area of Expertise & \\
\hline Date of Interview & \\
\hline Interview Medium & \\
\hline
\end{tabular}

\section{Section A: Interview Questions from Faculty Members}

1. Do you think virtual learning can compensate face-to-face learning?

2. What challenges you had to face to switch to online teaching? And how you managed to deal with those challenges?

3. Students perform better in virtual learning than on campus learning?

4. Please mention a few virtual learning strategies you adopted to make your class more interactive and effective.

5. What educational practices do you think lack in Pakistan that could aid a smooth transition to online learning?

6. What conditions according to you influence the effectiveness of virtual leaning?

\section{Section B: Interview Questions from Higher Administration of University}

1. How many courses are being taught online at University of Lahore?

2. As University of Lahore is the second largest university in Pakistan in terms of student body. How did you manage to switch to online learning after lockdown in March this year?

3. What strategies you adopted to train your technical team and teachers for a smooth transition to virtual learning from face-to-face learning?

4. Do you have any system in place to address student's grievances?

5. COVID 19 has created unprecedented times for almost everyone around the globe. What conditions do you think influence the effectiveness of online learning?

6. What challenges you have to face on daily basis to maintain the quality of online learning?

7. Where does University of Lahore stands in the overall ranking of virtual learning in Pakistan?

8. Are you satisfied with the steps you have taken so far for virtual learning at the University?

\section{Section C: Interview Questions from IT Head}

1. How many students you have enrolled online?

2. Which online systems / software you have in place at University of Lahore for virtual learning?

3. Do you organize regular trainings of your technical staff for the smooth running of the online system?

4. What challenges you had to face to switch to online system?

5. Do you consider your efforts in line with the virtual learning recommendations given by HEC? (Technical efforts) 